\title{
MANAJEMEN PENGOLAHAN KELOMPOK SAMPAH
}

\author{
Mutia Tri Satya \\ rafi_afia@yahoo.com \\ Yuyus Yudistria \\ y.yudistria@yahoo.com \\ Ayi Tejaningrum \\ tejaningrumayi@gmail.com
}

\section{SEKOLAH TINGGI ILMU EKONOMI EKUITAS}

\begin{abstract}
ABSTRAK
Dari sisi perekonomian, masyarakat Desa Margasari ada di kelas menengah ke bawah. Pendapatan yang kecil dengan biaya hidup yang tinggi. Untuk membantu kebutuhan rumah tangga, ibu-ibu di Desa Margasari berusaha untuk membantu ekonomi rumah tangga dengan cara berjualan di sekitar sekolah. Kondisi setelah masyarakat memahami tentang pemilahan sampah, dan bahwa sampah anorganik bisa menghasilkan keuntungan dari sisi materi. Tim pengabdian menginisiasi membentuk kelompok pengolahan sampah bagi ibu-ibu di Desa Margasari. Metode dalam program pengabdian yang dilakukan adalah tahap awal identifikasi permasalahan kelompok, kemudian pelatihan sesuai dengan kebutuhan kelompok (manajemen pengolahan dan pencatatan keuangan). Kemudian tahap pelaksanaan, yaitu dilakukanya pelatihan manajemen pengolahan dan pencatatan keuangan dan tahap akhir dilakukannya pendampingan. Hasil pengabdian ini antara lain: 1). Peserta mengetahui faktor penghambat dan pendukung yang dihadapi oleh kelompok pengolahan sampah; 2). Peserta manajemen pengolahan sampah yang baik sehingga terstruktur dan tertib administrasi adanya pembagian tugas; 3). Peserta dapat membuat pencatatan keuangan yang baik; 4). Peserta dan masyarakat sekitar memahami keuntungan dengan adanya ke bank sampah dan pentingnya legalitas dari sebuah kegiatan yaitu dengan di bentuknya koperasi; 5). Peserta dapat mengoperasikan mesin jahit sehingga dapat menghasilkan berbagai jenis barang dari sampah.
\end{abstract}

Kata kunci: Manajemen, Pengolahan, Sampah.

\section{PENDAHULUAN}

Margasari adalah desa yang berada di kecamatan Puloampel Kabupaten Serang, Banten Indonesia. Walaupun secara geografis termasuk pada wilayah perkotaan karena langsung berada pada jalan protokol. Daerah ini merupakan daerah pertambangan, dimana hasil tambangnya dibawa ke Jakarta, Kalimantan sampai ke
Singapura. Untuk itulah, kenapa banyak industri di sekitar desa itu.

Sekitar $70 \%$ masyarakat bekerja sebagai buruh di Industri. Sisanya ada yang bertani, berternak atau tidak bekerja. Dari sisi perekonomian, masyarakat desa Margasari ada di kelas menengah ke bawah. Pendapatan yang kecil dengan biaya hidup yang tinggi. Untuk membantu kebutuhan 
rumah tangga, ibu-ibu di desa Margasari berusaha untuk membantu ekonomi rumah tangga dengan cara berjualan di sekitar sekolah.

Berdasarkan survey yang sudah di lakukan, kami melihat banyaknya sampah yang ada disekitar desa ini. Kami mencoba memberikan peluang dengan memanfaatkan sampah yang ada. Awalnya kami memberikan pengetahuan tentang pemisahan sampah organik dan anorganik. Menurut penelitian, penduduk Indonesia menghasilkan 60-70 persen sampah organik, sisanya 30-40 persen adalah sampah anorganik.

Masyarakat memahami tentang pemilahan sampah ini, dan kami juga mengedukasi bahwa sampah anorganik ini bisa menghasilkan keuntungan dari sisi materi. Kami memotivasi mereka untuk membentuk kelompok. Dan terbentuklah kelompok yang terdiri dari ibu-ibu ke dalam kelompok pengolahan sampah.

Kelompok pengolahan sampah ini berjalan dengan baik. Dengan membuat jadwal untuk penimbangan sampah setiap satu minggu sekali dan dijual ke pengepul. Masing-masing sampah anorganik mempunyai nilai ekonomis yang berbeda. Ada jenis sampah plastik, besi, kertas, dan botol plastik.

Jumlah anggotanya bertambah tidak hanya ibu-ibu saja tapi juga anak-anak sekolah dilibatkan juga. Dengan keterlibatan anak-anak ini semakin bertambah pula keuntungan yang didapat. Melihat animo yang sangat besar, kami berencana untuk membentuk koperasi bank sampah. Namun sayangnya masih banyak hal yang harus diperbaiki terutama dalam hal pencatatan keuangan. Selama ini yang mereka lakukan

hanya mencatat di kertas selembar sehingga tidak jarang catatannya hilang. Untuk inilah kami bermaksud melakukan pelatihan tentang manajemen pengolahan sampah, terutama dari sisi keuangan.

Permasalahan dari sisi manajemen dan struktur organisasinya, masih belum jelasnya struktur organisasi yang berakibat terhadap tidak jelasnya job description masing-masing anggota. Jadi kemungkinan setiap anggota akan melakukan pekerjaan yang double.

\section{METODOLOGI PELAKSANAAN}

Kegiatan pelaksanaan kegiatan yang akan dilaksanakan dibagi menjadi 3 tahap yaitu Tahap awal, Tahap pelaksanaan dan Tahap akhir (monev) atau kegiatan pelaksanaan tersebut sebagai berikut:

Iahap Awal

Berdasarkan tahapan pelaksanaan tersebut maka rincian rencana pelaksanaan kegiatan adalah sebagai berikut:

\section{Tabel 1. Rencana Kegiatan Pengabdian}

\begin{tabular}{|l|l|l|}
\hline $\begin{array}{c}\text { Rencana } \\
\text { Kerja }\end{array}$ & $\begin{array}{c}\text { Metode } \\
\text { Pendekatan } \\
\text { Dan } \\
\text { Penerapan } \\
\text { Iptek }\end{array}$ & \multicolumn{1}{|c|}{$\begin{array}{c}\text { Prosedur } \\
\text { Kerja }\end{array}$} \\
\hline $\begin{array}{l}\text { Tahap } \\
\text { awal }\end{array}$ & $\begin{array}{l}\text { Identifikasi } \\
\text { permasalahan } \\
\text { dalam } \\
\text { kelompok } \\
\text { pengolahan } \\
\text { sampah }\end{array}$ & $\begin{array}{l}\text { Menyusun } \\
\text { permasalahan } \\
\text { yang dihadapi } \\
\text { dan meranking } \\
\text { permasalahan } \\
\text { yang ada }\end{array}$ \\
\cline { 2 - 3 } & $\begin{array}{l}\text { Pembuatan } \\
\text { program } \\
\text { pelatihan } \\
\text { manajemen } \\
\text { pengolahan } \\
\text { sampah }\end{array}$ & $\begin{array}{l}\text { program } \\
\text { pelatihan } \\
\text { manajemen } \\
\text { pengolahan } \\
\text { sampah }\end{array}$ \\
\hline $\begin{array}{l}\text { Tahap } \\
\text { pelaksan } \\
\text { aan }\end{array}$ & $\begin{array}{l}\text { Pelatihan } \\
\text { pencatatan }\end{array}$ & $\begin{array}{l}\text { Penyusunan } \\
\text { pencatatan }\end{array}$ \\
\hline
\end{tabular}




\begin{tabular}{|l|l|l|}
\hline $\begin{array}{c}\text { Rencana } \\
\text { Kerja }\end{array}$ & $\begin{array}{l}\text { Metode } \\
\text { Pendekatan } \\
\text { Dan } \\
\text { Penerapan } \\
\text { Iptek }\end{array}$ & \multicolumn{1}{|c|}{$\begin{array}{c}\text { Prosedur } \\
\text { Kerja }\end{array}$} \\
\hline & $\begin{array}{l}\text { keuangan } \\
\text { sederhana } \\
\text { Sosialisasi } \\
\text { koperasi bank } \\
\text { sampah } \\
\text { Pelatihan } \\
\text { penggunaan } \\
\text { mesin jahit } \\
\text { untuk produk } \\
\text { pengolahan } \\
\text { sampah }\end{array}$ & $\begin{array}{l}\text { keuangan } \\
\text { sederhana } \\
\text { Pelaksanaan } \\
\text { Sosialisasi } \\
\text { koperasi bank } \\
\text { sampah } \\
\text { Pelaksanaan } \\
\text { pelatihan } \\
\text { penggunaan } \\
\text { mesin jahit } \\
\text { untuk produk } \\
\text { pengolahan } \\
\text { sampah }\end{array}$ \\
\hline $\begin{array}{l}\text { Tahap } \\
\text { akhir }\end{array}$ & $\begin{array}{l}\text { Monitoring dan } \\
\text { Evaluasi }\end{array}$ & $\begin{array}{l}\text { Pendampingan } \\
\text { sampai tercipta } \\
\text { produk } \\
\text { pengolahan } \\
\text { sampah dan } \\
\text { pencatatan } \\
\text { keuangan }\end{array}$ \\
\hline
\end{tabular}

Jenis luaran kegiatan ini antara lain:

1. Pencatatan keuangan yang terencana dengan baik.

2. Masing-masing anggota mengetahui kondisi keuangan kelompoknya.

3. Produk-produk pengolahan sampai yang berkualitas dan mempunyai nilai jual.

\section{HASIL DAN LUARAN}

Dalam manajemen pengolahan sampah terlebih dahulu dilakukan identifikasi identifikasi permasalahan dalam kelompok pengolahan sampah yang diperoleh sebagai berikut:

\section{Faktor Penghambat}

1) Kurangnya kemampuan dari anggota kelompok pengolahan sampah, dikarenakan pendidikan yang rendah.

2) Pembukuan tabungan sampah dan keuangan yang belum tersusun dengan baik
3) Pemahaman bahwa tujuan pendirian bank sampah Resik Jeliger untuk mengurangi timbulan sampah. Sehingga yang harus dtiingkatkan adalah jumlah anggota dan frekuensi penyetoran sampah.

4) Hasil kerajinan belum rapi dan belum terorganisasi.

5) Perlu dibuatnya koperasi.

6) Kendala terbesar adalah basecamp tempat anggota menyimpan kebutuhan kerajinan, hasil kerajinan dan ATK Bank Sampah Resik Jeliger.

7) Frekuensi penyetoran sampah masih 2 minggu sekali. Seharusnya 1 minggu sekali agar sampah tidak menumpuk dan penambahan anggota bank sampah lebih cepat terealisasi.

8) Hasil kerajinan belum rapi.

9) Anggota belum mendapat solusi pengelolaan sampah organik.

\section{Faktor Pendukung}

1) Tanggapan positif lingkungan anggota Bank Sampah Resik Jeliger. Terlihat dari keterlibatan anggota keluarga terhadap pemilahan dan pengumpulan sampah anorganik.

2) Antusiasme anggota keluarga yang turut serta membuat kerajinan limbah kemasan kopi.

3) Kegiatan Bank Sampah Resik Jeliger tetap berlangsung walau mengalami banyak kendala seperti timbangan rusak dan tidak adanya basecamp.

4) Pada akhir pertemuan, peserta mengumpulkan sampah anorganik, bekas makan dan minum.

5) Tanggapan positif lingkungan anggota Bank Sampah Resik Jeliger. Terlihat dari keterlibatan anggota keluarga terhadap pemilahan dan pengumpulan sampah anorganik.

6) Tanggapan positif pihak sekolah untuk menjadi bagian dari Bank Sampah Resik Jeliger.

Berdasarkan hasil identifikasi kondisi permasalahan kelompok tersebut program yang kami lakukan berupa pelatihan manajemen dan pembukuan sederhana. 
Dalam pelatihan manajemen kami menggambarkan pentingnya manajemen di dalam satu organisasi. Dengan memahami manajemen kelompok ini mengerti tentang struktur organisasi dan pembagian kerja setiap anggota nya.

Sebelum ada pelatihan ini, manajemen kondisinya masih tidak berarturan, beban tugas hanya dilakukan oleh ketua dan wakil ketua kelompok. Dengan pekerjaan yang berlebih hasilnya menjadi tidak maksimal dan tidak berarturan.

Sama hal nya dengan masalah pembukuan masih kurang tersusun dengan baik. Sehingga banyak pencatatan yang hilang. Ini sangat merugikan anggota dengan hilangnya data penyetoran sampah dan nilai uang yang didapat.

Dengan adanya pelatihan pembukuan sederhana, anggota memahami pentingnya pencatatan yang baik. Pembagian kredit dan debit dalam perencanaan keuangan. Sehingga setiap anggota mengetahui berapa nilai keuangan yang didapat. Dengan jelasnya perencanaan keuangan bisa meningkatkan motivasi mereka untuk mengolah sampah dengan baik

Tabel 2. Hasil Pelaksanaan

\begin{tabular}{|c|c|c|}
\hline $\begin{array}{c}\text { Rencana } \\
\text { Kerja }\end{array}$ & $\begin{array}{c}\text { Metode } \\
\text { pendekatan }\end{array}$ & Hasil \\
\hline \multirow[t]{2}{*}{ Tahap awal } & $\begin{array}{l}\text { Identifikasi } \\
\text { permasalaha } \\
\text { n dalam } \\
\text { kelompok } \\
\text { pengolahan } \\
\text { sampah }\end{array}$ & $\begin{array}{l}\text { Diketahuinya } \\
\text { factor } \\
\text { penghambat } \\
\text { dan pendukung } \\
\text { yang dihadapi } \\
\text { oleh kelompok } \\
\text { pengolahan } \\
\text { sampah }\end{array}$ \\
\hline & $\begin{array}{l}\text { Pembuatan } \\
\text { program } \\
\text { pelatihan } \\
\text { manajemen } \\
\text { pengolahan } \\
\text { sampah }\end{array}$ & $\begin{array}{l}\text { Peserta } \\
\text { kelompok } \\
\text { pengolahan } \\
\text { sampah } \\
\text { memahami } \\
\text { bagaimana } \\
\text { manajemen } \\
\text { pengolahan } \\
\text { sampah yang } \\
\text { baik sehingga } \\
\text { terstruktur dan } \\
\text { tertib } \\
\text { administrasi }\end{array}$ \\
\hline
\end{tabular}

\begin{tabular}{|c|c|c|}
\hline & & $\begin{array}{l}\text { adanya } \\
\text { pembagian } \\
\text { tugas }\end{array}$ \\
\hline \multirow[t]{3}{*}{$\begin{array}{l}\text { Tahap } \\
\text { pelaksanaan }\end{array}$} & $\begin{array}{l}\text { Pelatihan } \\
\text { pencatatan } \\
\text { keuangan } \\
\text { sederhana }\end{array}$ & $\begin{array}{l}\text { Peserta } \\
\text { kelompok } \\
\text { pengolahan } \\
\text { sampah paham } \\
\text { dan dapat } \\
\text { membuat } \\
\text { pencatatan } \\
\text { keuangan yang } \\
\text { baik }\end{array}$ \\
\hline & $\begin{array}{l}\text { Sosialisasi } \\
\text { koperasi } \\
\text { bank } \\
\text { sampah }\end{array}$ & $\begin{array}{l}\text { Peserta } \\
\text { kelompok } \\
\text { pengolahan } \\
\text { sampah dan } \\
\text { umumnya } \\
\text { Masyarakat } \\
\text { sekitar } \\
\text { memahami } \\
\text { keuntungan } \\
\text { dengan adanya } \\
\text { ke bank sampah } \\
\text { dan pentingnya } \\
\text { legalitas dari } \\
\text { sebuah kegiatan } \\
\text { yaitu dengan di } \\
\text { bentuknya } \\
\text { koperasi }\end{array}$ \\
\hline & $\begin{array}{l}\text { Pelatihan } \\
\text { penggunaan } \\
\text { mesin jahit } \\
\text { untuk } \\
\text { produk } \\
\text { pengolahan } \\
\text { sampah }\end{array}$ & $\begin{array}{l}\text { Peserta } \\
\text { kelompok } \\
\text { pengolahan } \\
\text { sampah dapat } \\
\text { mengoperasika } \\
\text { n mesin jahit } \\
\text { sehingga dapat } \\
\text { menghasilkan } \\
\text { berbagai jenis } \\
\text { barang dari } \\
\text { sampah }\end{array}$ \\
\hline Tahap akhir & $\begin{array}{l}\text { Monitoring } \\
\text { dan Evaluasi }\end{array}$ & $\begin{array}{l}\text { Melakukan } \\
\text { pendampingan } \\
\text { sampai tercipta } \\
\text { produk } \\
\text { pengolahan } \\
\text { sampah dan } \\
\text { pencatatan } \\
\text { keuangan }\end{array}$ \\
\hline
\end{tabular}




\section{KESIMPULAN}

Berdasarkan hasil pelaksanaan kegiatan maka dapat disimpulkan beberapa point, yaitu:

1. Diketahuinya faktor penghambat dan pendukung yang dihadapi oleh kelompok pengolahan sampah.

2. Peserta kelompok pengolahan sampah memahami bagaimana manajemen pengolahan sampah yang baik sehingga terstruktur dan tertib administrasi adanya pembagian tugas.

3. Peserta kelompok pengolahan sampah paham dan dapat membuat pencatatan keuangan yang baik.

4. Peserta kelompok pengolahan sampah dan umumnya Masyarakat sekitar memahami keuntungan dengan adanya ke bank sampah dan pentingnya legalitas dari sebuah kegiatan, yaitu dengan dibentuknya koperasi.

5. Peserta kelompok pengolahan sampah dapat mengoperasikan mesin jahit sehingga dapat menghasilkan berbagai jenis barang dari sampah.

\section{DAFTAR PUSTAKA}

Aryeti. (2011). Peningkatan Peranserta Masyarakat Melalui Gerakan Menabung pada Bank Sampah di Kelurahan Babakan Surabaya, Kiaracondong Bandung. Jurnal Permukiman, Vol. 6 No. 1 April 2011: 40-46.

Hakim, M., Wijaya, J., Sudirja, R. (2006). Mencari Solusi Penanganan Masalah Sampah Kota. Bandung Direktorat Jenderal Hortikultura, DEPTAN RI.

Sejati, K. (2009). Pengolahan Sampah Terpadu. Yogyakarta: Kanisius.

Tobing, I. S. L. (2005). Dampak Sampah terhadap Kesehatan lingkungan dan Manusia. Makalah pada Lokakarya "Aspek Lingkungan dan Legalitas Pembuangan Sampah serta Sosialisasi Pemanfaatan Sampah Organik sebagai Bahan Baku Pembuatan Kompos"
Kerjasama Universitas Nasional dan DIKMENTI DKI. Jakarta.

http://id.wikipedia.org/wiki/Pengelola an_sampah diakses tanggal 5 Oktober 2015.

http://majarimagazine.com/2007/12/teknolo gi- pengolahan-sampah/ usaha pengelolaan sampah masyarakat diakses tanggal 8 Oktober 2015. 